\title{
The Marketing of Agricultural Products and Its Theoretical Analysis
}

\author{
Dingju Xiao \\ Chongqing Technology and Business Institute, Chongqing, 401520
}

Keywords: Agricultural Products, Theoretical Analysis, Marketing Strategy

\begin{abstract}
In the new stage of development of agriculture in China, the domestic market has changed with the shortage of agricultural products into regional surplus or structural surplus. The demand structure and demand quantity of agricultural products have also changed greatly. The prices of agricultural products have been declining and the selling The situation. With the accession to the WTO, open the agricultural market, the national treatment will lead to more intense domestic market competition, China's agriculture as a low degree of market-oriented industries will face severe challenges. To improve the international market competitiveness of agricultural products, accelerate the process of agricultural market reform, the implementation of agricultural marketing is imperative.
\end{abstract}

\section{Introduction}

The consumer demand is the starting point, the center point and the homing point of the agricultural production operator. Market economy conditions The production of agricultural products must be oriented to the market, that is, according to the needs of consumers and desire to decide what to produce. This requires that producers and producers of agricultural products not only study the real needs of people, but also to study the demand for agricultural products and create demand, through the production, transmission of agricultural products and the final consumption of agricultural products to meet customer needs. Such as: what kind of fruit consumers prefer? Which varieties of pork by the preference? Production operators know the market information, according to information to adjust their production resources and determine the type of production. This is the traditional production conditions determined by the production of varieties, after production, and then try to sell is different. That marketing is not beginning at the end of production, often before the product is not produced.

Agricultural marketing is an integral marketing process that includes agricultural production activities. There are two layers of meaning: the first is the agricultural production activities as a part of marketing activities, the traditional agricultural products circulation is the agricultural activities after the commercial activities, the production of agricultural products known as agriculture, the circulation of agricultural products into the field of commercial activities, Artificially separated. Second, the marketing of agricultural products is a whole marketing process, the production process of agricultural products is not only refers to the cultivation, feeding process, all can create or increase the effectiveness of the product process are called production, so agricultural marketing is the continuation of all aspects of agricultural production, different Is that agricultural production is the original production, and marketing activities are secondary production. That is, agricultural marketing is an overall marketing process, the link can not be broken down by the division of labor in the agricultural production process, only as an organic whole can more effectively serve the target market.

Agricultural marketing through various activities continue to create a variety of product utility. The marketing link of the marketing of agricultural products creates the form utility for the consumer, the transportation part creates the regional utility of the product, the storage part creates the time effect of the product, the ownership of the transaction process product is transferred from the seller to the buyer, resulting in possession. That is, marketing of agricultural products through 
the various aspects of the service to improve the effectiveness of consumer satisfaction. For example: farmers produce rice, and consumers need rice, so the marketer should be rice grinding into rice, in the form of rice for sale. If the pace of life with the accelerated, people need to avoid Amoy pure rice, marketers can also provide consumers with this program of service, to produce free rice, improve product value, to meet consumer demand.

\section{Characteristics of Agricultural Products}

Lack of flexibility in the supply of agricultural products. The production of agricultural products is different from the characteristics of industrial production: First, industrial products can be started at any time production, that is, to continue to produce and decide how much production. While the production of agricultural products with seasonal characteristics, and the production cycle determined by the growth period of agricultural products. Second, industrial products can be temporarily due to reduced demand for storage, waiting for the opportunity to re-sale. While the majority of agricultural products with perishable, high storage costs, can not be long-term storage. Therefore, when the market agricultural products in short supply, the price rise, agricultural producers due to seasonal, growth factors, can not immediately increase production, and because there is no inventory of agricultural products (except food) regulation, resulting in short-term supply of agricultural products can not be with the price And increase. When the supply of agricultural products in the market is over and the prices are reduced, the supply of agricultural products can not be reduced with the price decline due to the fact that production can not be reduced immediately in the harvest season and can not be reduced by long-term storage. This shows that the supply of agricultural products is small, that is, lack of flexibility.

The supply curve of agricultural products is one - way curve. The supply curve for an industrial product is a curve extending from the lower left to the upper right, and when the price rises, the supply increases; when the price falls, the supply decreases along the original supply curve. But most of the supply of agricultural products does not meet this law, when the price increases, the supply increases, the price $\mathrm{Bu}$, the supply is not reduced along the original supply curve, but along the other less flexible supply curve to reduce, even along a The negative slope of the supply curve increases.

\section{Agricultural Marketing Problems}

With the intensification of competition in the international market of agricultural products, the competitive form has shifted from a single price competition to the quality competition of agricultural products. First of all, China's major agricultural products and foreign agricultural products, the quality gap is uneven. Such as: rice, foreign consumers like long grain rice, and China's high-quality rice grain average length of $6.8 \mathrm{~mm}, 0.4 \mathrm{~mm}$ than the international famous rice; 1000 grain weight average of 16.7 grams, 0.85 grams less than foreign brands; Taste quality of amylose content, foreign brands of rice an average of $20.0 \% 1$, China's eight high-quality rice average of $18 . \% 5$, the gap is large. Wheat, China's wheat varieties and foreign representative varieties in the main quality indicators are not very different, only in the protein content, lysine content than the average lower than the foreign varieties 1, but in the special powder, special powder on the wide range of special varieties, Not only the number of missing, and poor quality. Corn, only in the amylose content and foreign varieties difference of 3 percentage points, there is a big gap, other indicators and foreign almost, but China's corn in the development of specialization less than foreign.

Second, the quality and safety of agricultural products is worrying, "table pollution" has become a hot topic of social concern. Consumers are increasingly demanding the safety of agricultural products. Safe agricultural products become the first selling point of the market, in the past we say "people eat food for the day", today is to be stressed that "food to the people of the day" of the time. In addition, the international and domestic markets on food safety requirements and a l gatekeeper is also more stringent. Over the years, the EU quality of agricultural products to monitor the 
escalation: the beginning just check the product itself, and later it is necessary to check whether the production workshop in line with health conditions, and later also check the product with or without drug residues, and now even the soil, water quality, air No pollution should be checked. In the export of agricultural products, due to toxic and hazardous substances caused by excessive rejection, return, destruction, claims also occur frequently. Look at the domestic market, Shanghai and other cities also implemented a market access system for agricultural products. The more the agricultural products enterprises can guarantee the quality of agricultural products to attract consumers.

Classification refers to the agricultural products in accordance with a certain attribute, divided into different grades, to facilitate access to market transactions and the development of prices. From the marketing "meet the demand" point of view, a kind of agricultural products should be in accordance with the quality of the most important attributes of the consumer classification, so that consumers can according to their needs to buy agricultural products, thereby promoting sales and lb province trading time. Since the production of agricultural products is affected by natural conditions, it is difficult for producers to control the yield and quality. Therefore, it is very important for agricultural products to be classified at the time of sale. After the grading of agricultural products, the transaction procedure is simplified and the price is simple and fair, saving transaction time and transportation cost, Expand the scope of sales. Such as: can be implemented to see the sample transaction, do not have to visit the scene to see the quality. Especially online transactions, as long as the product level, quality can be described out. Agricultural products are divided into different grades, to meet the different levels of consumer demand and different purposes.

\section{Improve the Marketing Environment of Agricultural Products}

At present, China's agricultural prices fell, farmers' income growth rate decreased, become the current agricultural development is facing outstanding problems. The reason is not the absolute surplus of agricultural products supply, but the supply situation and market demand does not adapt to the relative surplus of products, causing prices to fall. In other words, from a micro perspective, farmers do not produce according to market demand caused by supply and demand imbalance, on the one hand the supply side of a large number of agricultural products can not sell, on the other hand the demand side of the product can not buy. Only the introduction of agricultural marketing concept, market-oriented, can be a good solution to this problem.

The current domestic agricultural production operators or business enterprises lack the concept of marketing, domestic and foreign trade in agricultural products mainly rely on a single cost advantage to achieve, short-term business behavior, means of operation, marketing methods and\} strategy can not meet the international and domestic consumer Capacity and consumption levels and changes in consumption structure needs. After joining WOT, the Western cheap, high-quality agricultural products, large-scale invasion, will impact on China's agricultural products market, when the domestic agricultural production and management enterprises will encounter great challenges. Only through marketing measures and strategies to comprehensively improve the competitiveness of China's agricultural products market in order to gain a firm foothold in the international market for trade liberalization. That is, China's agriculture in order to enhance their own competitiveness, agricultural products in order to stand on the market, and foreign products to compete to improve the backward sales of agricultural products, the use of marketing ideas and technology to sell agricultural products to promote the market On the line.

China should take the opportunity of agricultural accession to the WTO, to the integration of agricultural management for the purpose of the complete integration of China's government management resources, change the government management functions to adapt to the market, to adapt to competition as the center, the establishment of a national marketing control system and improve a variety of marketing management System to enhance the competitiveness of China's agriculture in the international market. At the same time, strengthen the government's service function of agricultural marketing. The second is to collect and publish agricultural products market letter from: Second, the development of agricultural products market rules to ensure fair trade of agricultural products; four is to clear the domestic and one), the main task of marketing agricultural 
products, Foreign agricultural marketing channels to ensure that agricultural products marketing a good external environment.

To break the regional agricultural products between the blockade and barriers to ensure that agricultural products nationwide free trade and fair trade; open up a variety of agricultural products between the regional "green channel" to ensure that different regions of agricultural products in the country circulation fast, smooth access. The establishment of a sound national agricultural products wholesale market, urban consumer market, urban markets and agricultural retail supermarkets, and actively explore the use of a large number of agricultural products, futures markets and futures transactions, the formation of functional, covering the country's agricultural market network. Improve the agricultural market and marketing laws and rules to ensure that the agricultural market and marketing a good legal environment. On the basis of the formation of a unified national agricultural products unified market.

To fundamentally overcome the agricultural products producers (farmers) scattered into the market a single drawbacks, will be a single scattered farmers organized, the establishment of various forms of agricultural marketing associations, agricultural brokers, on the basis of the formation of a national professional marketing association Or agricultural associations. Improve the negotiating strength and ability of agricultural producers (farmers) in marketing. Support and nurture agricultural enterprises, especially agricultural industrialization leading enterprises, to promote agricultural enterprises and farmers signed a variety of agricultural marketing contracts and agreements. Establish and improve the marketing system of agricultural products, including direct marketing organization and marketing service organization, such as agricultural wholesalers, agents, brokers, retailers, import and export enterprises, agricultural products processing enterprises, transportation enterprises, market information departments and so on. Only the mature marketing organization entity, in order to ensure that the main marketing of agricultural products organization, behavior in place.

\section{Conclusion}

For a long time, China's agricultural department in the planned economy stage, the shortage of products market environment and strong government resource allocation behavior seriously hampered the development of marketing functions. Producers and consumers in a state of isolation. After the reform and opening up, due to the gradual development of market agriculture and the rapid increase of agricultural labor productivity, especially the relative surplus of agricultural products and increase the income of the plight of non-increase, forcing our agriculture from the production, promotion gradually transition to marketing agriculture. However, compared with the developed capitalist countries, China's market economy system in the perfect and perfect marketing rules of the gap is very obvious. From China's agricultural market reform process is evident.

\section{References}

[1] Zheng Shujuan. Malaysian durian products are allowed to export to the Chinese market [J]. World Tropical Agriculture Information. 2016 (07)

[2] Zhang Zhaofeng. On the county of agricultural products marketing status and development trends [J]. Time Finance. 2014 (05)

[3] Du Xiaofeng, Xu Min.China's agricultural product marketing development status and innovative way [J]. Modern business. 2014 (12)

[4] Dai Yongxiu, Dai Yongwen, Fu Zunbin. Talking about the marketing of agricultural products [J] .Acommunication Forum (the second half). 2010 (10)

[5] five measures to do a good job of agricultural marketing marketing [J]. Rural Finance Accounting. 2009 (11) 